\author{
Ольга Николаевна Крылова \\ Институт лингвистических исследований РАН \\ Санкт-Петербург \\ ORCID: 0000-0002-6887-4316; e-mail: krylova_olga2004@mail.ru
}

\title{
«Дочку в колыбельку, приданое в коробейку»: название приданого в севернорусских говорах
}

\begin{abstract}
Реферат: В статье рассматривается один элементов свадебного ритуала - приданое и все, что с ним связано (процесс, время его приготовления, наименование лиц, перевозивших его). Выделены признаки, которые легли в основу наименований приданого. Наибольшее количество номинаций связано с его дарением (дар, дары, даровье, дарьё, задарье, вздарье); с одеждой и постелью, как части приданого (справа, свита, лопоть, лотонье, платно, место, перина); с коробом, в котором оно перевозилось (коробейка, коробья, кладовица, кошева).
\end{abstract}

Ключевые слова: севернорусские говоры, диалектная лексика, свадьба, приданое.

\begin{abstract}
Daughter in a cradle, the dowry in a small box»: names for the dowry in the North Russia dialects. The article examines one element of the wedding ritual: the dowry and everything related to it (the process, the time of preparation, the names of the individuals transporting it). The author has highlighted the features at the basis of the names of the dowry. The largest number of nominations are associated with its donation (dar, dary, darov'ye, dar'yo, zadar'ye, vzdar'ye); with clothes and bedding as part of a dowry (sprava, svita, lopot', loton'ye, platno, mesto, perina) and with the box in which it was transported (korobeyka, korob'ya, kladovitsa, kosheva).
\end{abstract}

Keywords: North Russian dialects, dialect vocabulary, wedding, dowry.

Для всестороннего и полного изучения лексической системы языка необходимо подробное описание диалектов, в том числе, тематических групп обрядовой терминологии. Как отмечает А.Ф. Журавлев, лексика обладает высокой степенью устойчивости на фоне других языковых уровней. Лексика способна гораздо дольше, чем фонетика и морфология, сохранять следы древних диалектообразующих сближений и расхождений (Журавлев 1992, 5).

Русский свадебный обряд состоит из множества элементов, среди которых выделяются: обрядовые песни, причеты, обязательные обрядовые действия невесты, дружки и других участников.

Неотъемлемой, особенно значимой частью ритуала для всех свадеб без исключения было приданое. Задолго до свадьбы мать девочки начинала готовить ей приданое. С 9 лет, а то и раньше, девочка уже помогала матери прясть и ткать. В Архангельской губернии существовала поговорка: «дочку в колыбельку, 
приданое в коробейку». В 13-15 лет девочка должна была себе сшить первую рубаху.

Девушки должны были думать о своем будущем семейном положении. Все их свободное время уходило на создание приданого, которое они приносили в дом мужа и которым обеспечивалась их отдельная семейная пара. Приданое считалось их собственностью даже в случаях разделов семей и семейных разводов. Оно состояло из предметов и вещей, изготовленных невестой или купленных на заработанные ею деньги от продажи производимых ею же продуктов. Это были одежда для себя и будущего мужа, белье, ткани домашнего изготовления, постель. Иногда в приданое давали скот, деньги, земельные участки.

К приданому можно отнести и все дары, получаемые невестой от ее родных и от родственников жениха: да'рье, сда'рье, сда'рьице, зда'рье, зда'рьеце (зда'рьице), взда'рье, приносы, плакальные деньги, так как все эти дары составляют собственность невесты.

Прино'с. В свадебном обряде - подарок невесте или молодым: Поутру невеста принимает приносы от своих родных и свадебников и каждому из низ плачет. Ботинки на принос, теперь приносов-то нету, а раньше были, раскливляли невесту-то, закрывали ее платом. Кого невеста призыва, тот и принос несет. Apx. ${ }^{1}$ (СРНГ, XXXI, 316). Пла'кальные деньги. В свадебном обряде: деньги, подаренные невесте, ее подругам при сговоре, смотринах или на свадьбе. «Перед смотринами (при которых совершается заплачка), невеста обходит приглашенных гостей, которые дарят ее при этом деньгами, называемыми плакальными». Пинеж. Арх., Подвысоцкий, 1885. Арх. (СРНГ, XXVII, 74). Да'рье. Свадебные подарки невесте, жениху и его родне, определенные при сговоре. Сольвыч. Волог., 1902 (СРНГ, VII, 278). Сда'рье. В свадебном обряде - денежные подарки невесте от родных и гостей. Шенк. Арх., 1852. Арх. «На сговоре - по выходе из-за стола, жених и поезжане идут на другую половину со сдарьем к невесте, отец женихов, тысяцкий и прочие поезжане дарят ее деньгами, за что она подает им по стакану пива и каждому кланяется в ноги». Арх., Описание Арх. губ., 1865 (СРНГ, XXXVII, 53). Сда'рьице. Ласк. В свадебном обряде - подарок (обычно кусок материи на платье). Я не могу осмелиться взять честного сдарьица. Велят (родители) - прикажут взять Честное сдарьиие - возьму - осмелюся (свадебн. песня). Шенк. Арх., 1920 (СРНГ, XXXVII, 54). Зда'рье. Подарки, деньги, которые дарят невесте в девичник жених, родственники жениха, сваты, гости. Шенк. Арх., 1854. Арх. Подарки невесте от жениха на свадьбе. Шенк. Арх., Матер. Срезневского. Деньги, которые дарят на свадьбе невесте родственники и гости. Шенк. Арх., 1846. Дары дарят - здарья хотят. Наша молодуха получила здарья 3 рубля. Сольвыч. Волог. (СРНГ, ХІ, 229). Зда'рьеце. Волог., 1902; зда'рьице. Tb пожалуй, тысяикий, Я зову, дожидаюся, Зову не для здарьица, для очного свиданьица. Вельск. Волог., 1862. Tbl попой, почествуй переварой пьяною всех многих людей для злата, серебра и для честного здарьииа. Арх. (СРНГ, ХІ, 229). Взда'рье. Подарки невесте от жениха и холостых мужчин в девичник. Арх., 1885 (СРНГ, IV, 258).

1 Все географические пометы даются так же, как в источнике. 
В Сольвычегодском уезде Вологодской губернии жених дарил невесте и всей ее родне подарки на четвертый день после сватовства: отдавать сда'рье. «Отцу, братьям и крестному по ситцевой рубахе и штанам, матери - рубаху со становиной, шаль или полушалок, крестной - шаль». Сольвыч. Волог,, Иваницкий, 1897 (СРНГ, XXXVII, 53). Обычай взаимного одаривания между женихом и невестой получил названия: дари'ны. «Невеста дарит белье своей пряжи, тканья и шитья, а жених - бабий головной убор, сороку». Даль [без указ. места]. Грязов. Волог., 1905 (СРНГ, VII, 273). Сда'рки, сда'рье. В свадебном обряде - подарки от жениха и невесты друг другу, а также родным, гостям и знакомым. Никол. Волог., Баженов (СРНГ, XXXVII, 53).

Подарков иногда было много: сшитые или только скроенные рубахи, платки, полотенца, сарафаны и т.д. Невеста одаривала жениха в последнюю очередь подносила ему платок, ширинку (полотенце).

В 70-х годах XIX века в Архангельской губернии женских рубах в приданом у девушки среднего состояния бывало 10 и более, а у богатых 30 и даже 50 рубах. Особенности в одежде различных по зажиточности групп крестьянства в середине XIX века выражались не столько в покрое и типе одежды, сколько в качестве тканей, употреблении ценных украшений. Богатая невеста должна была иметь весь набор сарафанов, начиная с дорогого шелковинка и кончая будничным крашенинником. Шелковинки, атласники, штофники и гарусники были дорогими, надевались по большим праздникам, и их количество у невесты указывало на уровень благосостояния семьи. Богатые девушки имели по несколько штук каждого вида сарафанов, невеста из семьи среднего состояния - только по одному. Самые бедные девушки и женщины совсем не имели атласников и гарусников, и самой их нарядной одеждой были кумачники и ситечники. Вследствие этого то небольшое количество домотканой одежды, которое они могли изготовить своими силами, они старались как можно наряднее украсить узорным ткачеством и вышивкой.

Девушку с богатым приданым в севернорусских говорах называли: Дарови'той. Взял-то он её замуж даровитую, пожни у ней хорошие были. Сямж. Расcox. (СВГ II: 7). Е'стешной (от есть 'достаток, богатство'). Невеста-то естешна! Волог. (СРНГ, IX, 42). Прида'нистой. Невеста-то приданиста была, отеи за ней иельй дом отписал. Арх. (СРНГ, ХXXI, 185). Также отмечены следующие наименования для богатой невесты: Богачу'нья. Богатая невеста, невеста с большим приданым. Каргоп. Олон. (Куликовский, 1989, 5). Прида'нница. Невеста с богатым приданым. Арх., 1885. Tы боярышня славянская. А сама ты разумнииза, Tы красавица - приданница (песня). Олон., Слов. Акад. 1961 (устар.) (СРНГ, XXXI, 186). Сприда'нница. Невеста с приданым. Обе девки у него сприданнищы. Межд. Волог. (СВГ, X, 104). Скру'тная невеста. Невеста с хорошим приданым. Арх., 1885 (СРНГ, ХXXVIII, 157). Славе'на, сла'вница, славну'ха, славу'тница, слову'тница. В старой деревне - дочь зажиточных родителей (чаще единственная), являющаяся привлекательной для возможных женихов. $У$ нас одна славена в деревне была. Тогда ведь все бедные были. Грязов. Волог. У славницы-то y нашей приданого много - хоть щяс замуж выходи. Сямж., Тотем., Сокол., Верх., Межд. Волог. (СВГ, Х, 42). Славнухи-то вперед всех замуж выходили: 
приданого-то вон сколько у них было. Грязов., Сокол., Волог., Вож. Волог. (СВГ, X, 43). Мать у меня была словутницей. Это значит, от хороших родителей. Ее, эту словутнииу-то, все оберегали, пьлинке не давали на нее упасть. Замуж выдавали не за лентяя, а за такого же словутника, работящего парня. Хоть она и словутницей была, но знала много. Кирил. Волог. Она славутницей была, так батько ей не разрешал с нами гулять. Вож. Волог. Что Марья бает, что словутнищей была? Забыла, как в лаптях ходила? Шексн., Волог., Никол., Харов., Волог. (СВГ, X, 44). Естё'вая невеста. Богатая невеста из состоятельной семьи. Невесту все естёвую искали (Лойма 1985). Естёвая - это девушка, у которой много тканого приданого (Лойма 1986) (Бунчук, 2012, 68).

Если девушка получала в приданое поземельный участок или деревню, то в Холмогорском и Шенкурском уездах Архангельской губернии ее называли дереве'нщицей (СРНГ, VIII, 11) или участницей (Ефименко 1872, 11). Невеста с плохим приданым - бесприда'нна. Арх., 1885 (СРНГ, ІІ, 274), или бесприданница.

Если муж приходил жить в дом жены, то есть становился приёмышем, приёмком, животником, то имение передавалось в его полное распоряжение. Приё'мок. То же, что приемыш. Никол. Волог., 1883-1889. Она выдала сноху [замуж] за крестьянина и приняла его в дом приемкам. Волог. Мне ништо и работать, Мне ништо и маяться Мне приемка не дают, Полоска не достанется. Онеж. КАССР (СРНГ, ХХХІ, 202). Приё'мыш. Зять, принятый в семью жены и живущий в ее доме. Олон., 1846. КАССР, Арх., Волог. В приёмыши попасть, отдать, жить, остаться приёмышом. В приемылии-то к ей и попал. Потом один пришел к ей и остался приёмышиом. Каргоп. Арх., 1971 (СРНГ, XXXI, 203). Живо'тник. Принятый в дом зять или жилец. Олон., Арх., 1823. Арх. «Когда брали в дом зятя, а не выдавали дочь на сторону, то его хозяйство, его имущество принимали в свое, как бы в складчину, в «складные животы»- общее имущество. С течением времени про такого зятя стали просто говорить: «B животы ' ушел!» или «Живо'тника взяли!» Так эти слова живут до наших дней». Арх., Зимин, 1965. Он, говорят, в животники выходит. Волог. (СРНГ, IX, 159).

Для обозначения приданого в севернорусских говорах употреблялось большое количество наименований. Среди них выделяются номинации, связанные:

1. С его дарением:

Дар. Приданое. Волог. (СРНГ, VII, 272). Да'ры. Приданое; подарки невесты жениху и его родне. А за невесту-та дары давали, обязательно это было. Сок. Волог. (СРГС, III, 177). Дары'. Свадебные подарки. «К концу девичника невеста приходит от соседа и раздает «дары». Гости кладут невесте за «дары» деньги». Волог. (СРНГ, VII, 271). Да'ры. Подарки жениху от невесты. Кадн. Волог, 1895 (СРНГ, VII, 271). Да'ры'. Подарки родственникам жениха со стороны невесты. Волог., 1902. «На родине Ломоносова особо и строго обсуждается еще при самом зарождении сватовства - как самое существенное в брачном уговоре, ибо жених останавливает все свои требования именно на этом. Подарки обязательны отцу и матери жениха, тысяцкому, братьям и сестрам, дру’жкам и всем родственникам жениха, званным на свадьбу. Ближней родне дарятся ситец на рубашки, материя на верхние одежды, шаферам и дальней родне платки - соответственно степени родства, а стряпухе особо - платок с куском мыла». Холмог. Арх., Грандилевский. 
Да'pы припасают. Да'ры припасают шиты. Неделю невесты посадят да'ры шить, девок созовут. Арх. Да'ры. Кадн. Волог., 1895. Дары'. Волог., Ленингр., Арх., Онеж. КАССР (СРНГ, VII, 272). Невёста-то что, бьвало, даров-то нашьёт! Баскиё, вылитыле, да всё и раздарить надо. Тот. Бор. Много надо было даров-то, по дисять аршин холста давали да всём по плату. К-Г. Новое дары-ти невеста по иелой недиле иила. Тарн. Заречье. Утром родители невестинь едут с сундуками, это уж дары везут - свёкру, свёкрове, золовкам. Баб. Дем. Погост. Невёста-то дары принимала да всё благодарила родных-то, кланялась. Даров-то всяких навезут, да много. Сок. Васил. Волог. (СВГ, II, 7). Дары' против даро'в. О подарках невесте и её родственникам в ответ на подарки жениху и его родственникам. Верх. Булын. (СВГ, ІІ, 8). Дарьё. Свадебные подарки (обычно холст, полотенца, платки и др.). Жёних приходит, дарьё несёт ей. Баб. Пожар. Много жених дарья-то принёс? Ник. Осин. (СВГ, II, 8). Даро'вье. Даровье невеста припасала для гостей. Сок. Кокош. (СВГ, ІІ, 7). Дарови'ца. Подарки невесты родне жениха. Кадн. Волог., 1895. Волог. (СРНГ, VII, 275). Дарену’ха, дарови'ца. Рубашка, которую невеста дарила свекрови. Ну-ко покажи даренуху-то, баская ли? Ну-ко, как вылшила даренуху-то, невеста? Нюкс. Климш. (СВГ, II, 6). Свекрови на свадьбе даровицу дарили, рубашку - верх ситиевой, стан холшшовый. Вож. Навол. Свекровке нужно подарить даровииу красивую. Вож. Сурк. (СВГ, II, 7). Даровииу надоть свекровке подарить, рубашку сошьют с рукавками и станом (Кон. Арх.). Не больно баска даровица-то. Влгд. (СГРС, III, 176). Даре'нница. Рубаха, которую невеста дарила свекрови. Рубаха даренница - невеста дарила свекрови. Арх. Уст. (СГРС, III, 175). Зада'рье. «Выговариваемые при сватовстве подарки от невесты отцу, матери и ближайшим родственникам жениха; также подарки, делаемые женихом и холостыми мужчинами невесте в девичник». Арх., (Подвысоцкий, 1885; СРНГ, Х, 43). Зда'рье. Подарки от «невесты отцу и матери и близким родственникам жениха. Сват, разрядивши лошадь жениха в лучшем уборе, с бубениами и позвонками, сватает невесту и выряжает здарье. Холм. Арх., 1877. «Недача здарья считается оскорблением родителей жениха и нередко бывает причиною расстройства свадьбы, а потому, если невеста бедна, то жених дает ей известную сумму денег на здарье. Худое, скудное здарье бывает поводом гонений против невестки». Онеж., Холмог., Пинеж., Шенк. Арх, Подвысоцкий, 1885. Сев.-Двин. (СРНГ, ХІ, 229). Взда'рье. Подарки от невесты отцу, матери и ближайшим родственникам жениха. Арх., 1885 (СРНГ, IV, 258).

2. С одной из его составных частей, которая дает название всему приданому:

a) с одеждой:

Спра'ва. Приданое невесты. У невесты богатая справа. Волог. (CPHГ, XL, 251). Сви'та. Приданое невесты; ее наряд. Это приданое невестино: плат атласной, казачок, атласник, пояс, перевяска. Каргоп. Арх., 1971 (СРНГ, XXXVI, 303). По'крут. Одежда, даваемая в приданое невесте. У невесты этой много покрутов. Волог., Олон., Даль (СРНГ, ХХІХ, 12). По'кру'та. Одежда, даваемая в приданое невесте. Покру'та. Заводить мне покруту, покрову великую. Онеж. Арх., 1864-1869. У той девки много есть покруты. Арх., Беломор., Олон., Волог. По'крута. У невесты этой много по'крутов. Заонеж., Петрозав. Олон., 18851898. Прионеж. Олон. (СРНГ, ХXIX, 13). Скру'та. Приданое невесты. Волог., 
1820. Когда девушку замуж отдавали, ей все припасут: утиральники, парочку атласну ли шелкову, кумачник и говорят - вся скрута есть. Арх. За девкой много скруты пошло. Север. (СРНГ, XXXVIII, 156). До свадьбы мать собирала девушке скруту. Тарног. Волог. Какой же ей замуж, ковды у ей и скруты нет! Межд. Волог. Вся скрута-то заведена у девки: платьё-то отласное, иляпа, колоши для форсу. Тотем. Волог. (СВГ, Х, 34). Ску'та. Одежда девушки, приготовленная ей в качестве приданого. Замуж выходила, дак много скутьл-то было. Харов. Волог. (СВГ, Х, 38). Ло'поть, лопать. Приданое. Ло'поть. Тотем., Устюж. Волог,, Баженов. Лопать [удар.?]. Тотем., Устюж., Никол., Волог., Волог. губ. вед., 1853 (СРНГ, XVII, 142). Лото'нье. Приданое невесты. Лотонье - приданое у нас так зовут. Каргоп. Арх., 1971 (СРНГ, XVI, 287). Платно'. Приданое невесты. Арх., 1867-1868 (СРНГ, XXVII, 97). Платное [удар.?]. Приданое невесты. Арх., 18671868 (СРНГ, XXVII, 97).

б) с постелью:

Ме'сто. Приданое. Невеста без места. Арх., 1950. Глядеть (смотреть) ме'сто (места'). В свадебном обряде - глядеть, осматривать хозяйство жениха. Волог. Поедут у жениха место смотреть. Арх. (СРНГ, XVIII, 128-129). Пери'на. Приданое невесты. Со перинами. Лодейноп. Ленингр. (СРНГ, XXVI, 282).

Постель готовилась непосредственно перед свадьбой. Бывали случаи, когда очень бедные невесты, чаще всего сироты, не имели своей постели (так называемая невеста без места), тогда им приходилось брать ее взаймы на время свадьбы.

3. Предоставлением, дачей, выдачей имущества в личную собственность:

При'да'но. Приданое. При'дано. Онеж. КАССР, 1983. Прида'но. Придана, пожалуй, не нитки. В долгу не деньги, а у тестя не придано. И большо придано не сделает мужа. Арх., 1885. Платенко прида'но. Приданое, заранее приготовленное и уложенное в сундуки. Арх., 1885 (СРНГ, ХХХI, 186). Пла'тенное придано (СРНГ, XXVII, 95). Прида'новое. Приданое. В приданово-то семь сарафанов было. Арх. (СРНГ, XXXI, 186). Прида'нница. Приданое. Арх., 1970. Давали много всего: две иконь, три подушки, гардероб цельии, во двух сондуках, все это приданница называли. Арх. Приданни'ца. Корова, лошадь или вещь, полученная в приданое. Холмог. Арх., 1907 (СРНГ, ХХХІ, 186). Прида'ны, мн. Приданое. Вилегод. Арх., 1957 (СРНГ, ХХХІ, 186). При'данье. Приданое. «Проводив невесту в церковь божию, с приданьем ее спешат в дом жениха». Вельск. Волог., Шайтанов, 1849. Олон. (СРНГ, ХXXI, 187). Да'нница. Приданое. «В Шенкурском уезде приданое называется также да'нье, а в Холмогорском уезде - да'нниияа. Данница-то у ей поди хорошая. Невеста у нас с большой данницей». Холмог. Арх., Подвысоцкий, 1885 (СРНГ, VII, 271). Да'нье. Приданое. Шенк. Арх. (Подвысоцкий, 1885). Так пропил, прожил житье-бытье свое. Житье-бытье свое да все приданое мое. Все приданое мое да да'нье материно. Арх. Пропил, прожил все житье бытье мое, Все приданое мое, Данье материно. Олон. (СРНГ, VII, 271).

4. С коробом, сундуком, в котором перевозится приданое:

Коробе'йка. Приданое; вышитые изделия, обычно входящие в приданое. Арх., 1885. Что эту девку замуж брать, у ней и коробейки нет. Медвежьегор. КАССР 
(СРНГ, XIV, 344-345). Коробья'. Сундук для приданого; приданое невесты (собираемое в сундук). Ко'робья. Арх., 1877. Пойдем, девка, посмотрим, а то сейчас коробью-то с животом (приданым) увезут. Волог. Коробья'. Волог., Арх. (СРНГ, XIV, 349). Кладови'ца. Приданое невесты. У меня кладовица была, в сундуке хранила (Лойма 1985). Раньше ложили в сундук, выливали полотенце, пряли, ткали, молодича пришла богатая, много кладовиџь (Лойма 1985) (Бунчук, 2012, 69). Кошева'. Приданое невесты. Пудож. Олон., 1854 (СРНГ, XV, 141).

5. С различными общими наименованиями имущества, пожитков:

Де'вье име'нье. Приданое. Арх. (Подвысоцкий 1885, 60). Прида'ный живот. Приданое. Приданым животом да наказанным умом не долго поживешь. Арх., 1885 (СРНГ, XXXI, 187). Живо'т. Приданое невесты. Сколько жывота у йей, гледи-ко, повезли на телеги. Раньшэ ведь жывоты возили, как неделя после свадьбы пройдёт. ХОЛМ. Слц. Жонка уходит, она свой жывод забират, а уш його-то не тронь. Вон яшшык ж жывотом везут. "Жывоты повезли»- когда придано-то повезут. ХОЛМ. ПМ. Через неделю йехали за жывотами. ХОЛМ. Задворье. Я взамуш-то выходила, у меня было восемь юбок да восемь кофточек, в жывотах фсё было. НЯНД. Врл. КАРГ. Ух. ШЕНК. ВП. (АОС, ХІV, 45-46). Добро. Приданое невесты. Сколько было добра ф клети! Мез. На двух возах привезли срятки фсякой да добра. В.-Т. УВ. Добро, богацьво, лопотину, срят. Вель. (AOC, XI, 191).

6. С долей общего имущества, которой наделяют невесту:

Наде'л. Приданое невесты (исключая платья). Арх., 1885 (СРНГ, ХІХ, 230). Наде'лка. Приданое невесты. Шенк. Арх., 1910 (СРНГ, ХІХ, 230). Наде'лок. Приданое невесты. Арх., 1885 (СРНГ, ХІХ, 231).

В Архангельской губернии, как отмечает П. Ефименко, крестьяне, однако, считали, что приданое и наделок имеют различие: приданое - это та одежда и украшения, которые заготовили отец и мать невесты; наделок - это деньги, корова и с ней сено, поля, пожни. Если мать дает свое старинное платье и другие наряды, полученные ею в свою очередь в приданое, то это тоже будет наделок (Ефименко 1872, 5).

7. С его перемещением в другую семью:

Вы'вод. Сумма денег, которую отец дает в приданое за дочерью. Кадн., Вельск., Тотем. Волог. (Дилакторский 2006, 71).

Среди других названий приданого выделяются следующие: Поса'жное. Приданое. Олон., 1856 (СРНГ, ХХХ, 137). Каргоп. Олон. (Куликовский, 1989, 90). Посаженное имущество. Приданое невесты. Посаженное имущество - это приданое, у девок наших оно было разное. Медвежьегор. КАССР, 1970 (СРНГ, XII, 195). Честь. Приданое. Придут от жениха-то сваты и смотрят, какая честь у невесть-то. К-Г. Волог. (СВГ, ХІІ, 38). Е'сьти, мн. Вещи из приданого; приданое. Сев.-Двин., 1928 (СРНГ, IX, 44; Есть. Достаток, богатство. Волог., 1849. Волог. (СРНГ, IX, 43).

Как уже отмечалось, приготовление приданого начиналось далеко до свадьбы. Девушка должна была своими руками выткать полотно, сшить одежду, белье и т.п. В период подготовки к свадьбе в этом ей помогали девушки и женщины. В севернорусских говорах это время получило следующие наименования: Дарока'танье. 
Часть свадебного обряда, накануне венчанья, когда подруги невесты гладят («выкатывают») предназначенные для подарков платки, полотенца и т.п. и подают их невесте, которая с причитаниями складывает их. Рукобитьие, дарока'таньие. Потом уж дарокатаньие. Бывало, дефку-то оддавали в дарокатаньие, ф канун-то свадьбы. ВЕЛЬ. (АОС, Х, 269). Пося'дки, поси'дки - время шитья приданого на Пинеге. «Девушки ходят работать к невесте, которая сидит в ними - принаряженная, но унылая и песен не поет» (Крестьянское искусство СССР 1928, 151). «Всю неделю после просватанья к невесте ходят ее подруги и помогают ее домашним шить приданое. Сама невеста в работе не участвует: она кланяется в ноги каждой подруге и причитает...» (Крестьянское искусство СССР 1928, 122). «В Суре во время шитья приданого девушки ходят к невесте с прялками и со своей работой, а приданое шьют только домашние невесты» (Крестьянское искусство СССР 1928, 124). Посе'дка. Собрание девушек в доме невесты накануне сговора (когда невеста со своими родными и подругами оплакивает свою девичью жизнь). Пинеж. Арх., 1850. Арх. Посе'дки. Бокситогор. Ленингр., 1970 (СРНГ, XXX, 146). Поси'дка. В свадебном обряде - девичник. Просватают невесту то, а вечером на посидку собирают, а уж на другой день з невестой едут. Пинеж. Арх., 1974. Поси'дки. Арх., 1885 (СРНГ, ХХХ, 159). Поси'дничать. Участвовать в посидках - девичнике накануне свадьбы. Я в синяке со строками и в белой рубахе посидничала, на посидке невестой причитала. Пинеж. Арх., 1959 (СРНГ, ХХХ, 159). Неве'стить. Шить, вышивать что-либо для подарка жениху. Пинеж. Арх., 1971 (СРНГ, ХХ, 335). Неве'ститься. Готовиться к свадьбе - шить себе наряды, собирать приданое. Просватают, дак потом иелу неделю невеста невестится, все приданое шьет. Пинеж. Арх., 1974 (СРНГ, ХХ, 335). Скру'точник. В свадебном обряде - вечеринка для подруг невесты в ее доме накануне свадьбы: девушки помогают собирать приданое, а невеста, причитая, просит мать принести ей самое лучшее платье. В скрутошник-то девушка плакала, ходила от платья $\kappa$ платью да и причитала. На срутошник к невесте подруги приходили. На скрутошнике невесту упевают. Сокол. Волог. (СВГ, Х, 35). Ши'тни'к. В традиционном свадебном обряде - вечер перед свадьбой, на котором невеста и её подруги шьют приданое. На ши'тнике пою'm пе'сни и шьют прида'ное. Тарн. Тюпр. Ши'тник де'лали. Де'вки, подру'жки, ии'ли ска'терти, руба'хи, полоте'нца. Неве'сте всё вкру'те не сде'лать! К-Г. Плоск. Шитни'к был, когда неве'ста сро'ком сиди'т. Подру'жки прихо'дят и шьют, что напригото'влено. К-Г. В. Ент., В-У. Волог. (СВГ, ХІІ, 92). Деви'чник. Собрание подруг невесты в досвадебный период. Перед плаканьем вот как будто собираются, девичник, вот последний день, соберутся все и вот пируют, тожо это было, девичник до плаканья, девичник пораньше, не ревут там, а гуляют, последний день потому что, у невесты завтра плаканьё (Лойма 2011). Девичник начинался вот когда жоних приходил посватался, и с этого начинают девичники, приходили подружки, и кто выпивал, кто вязал, и до дня свадьбы (Тарасовская 2011) (Бунчук 2012, 68). Плака'нье и плака'ньё. Довенечная часть свадебного обряда: собрание в доме невесты, в это время исполнялись свадебные причитания. Договорятся, сделают первое плаканнё, сегодня, скажем, плаканнё, а завтра свадьба (Лойма 2008). Плаканье устроят - девку замуж отдают когда, последний день баню белую топят, в баню 
сводят, потом все придут девки плакать, замуж котора идёт, к ей все приходят (Лойма 2011). Собирают у невесть плаканье, вся родня невестина собираются, стол накрыт и ждут жониха (Уркинская 2011) (Бунчук 2012, 71-72). Пла'канье. Девичник. «Плаканье устраивается в доме невесты накануне свадьбы. Невеста сидит в кути и по приходе подружек поет им с помощью причитальницы - женщины, руководящей свадебными песнями». Кадн. Волог., Иваницкий, 1890. Волог. (СРНГ, XXVII, 75).

Процесс приготовления приданого представлен в говорах следующими лексемами и фразеологизмами: Дары' ката'ть (проката'ть). Готовить свадебные подарки (о невесте и ее подругах), подвешивая их на специальную жердь. Девки собираются дары катать, да тут хрястанья да рёву. Уст. Арх. Дары еще прокатают на палку такую с рубцам, а с жениховой стороны сколько даров попросят. В-Уст. Волог. (СГРС, 3, 177). Крути'ть. Припасать приданое; готовить наряды и украшения к свадьбе. Они растили сердечных ваших детушек, Все крутили нас победнылх головушек (причит.). Барсов [без указ. места]. Крути'ть коробейку, коробью. Готовить приданое невесте. Тонко пряла, ситно ткала, коробейку крутила (свадебн. приговор). Арх., 1862. Слов. карт. ИРяЗ [с пометой «обл.»] (СРНГ, XV, 327). Коробью' крутить, коробья' копить. Готовить приданое. Арх., 1867-1868. Рядить ко'робью (коробью'). Складывать в сундук приданое; готовить приданое. Даль [без указ. места]. Арх., 1885 (СРНГ, XIV, 349). Коробе’йку крутить. Копить приданое. Коробейку-то крутишь, Валя? К-Г. Мит. Гора. (СВГ, III, 106). Обряжать невесту. Шенк. Арх. (Ефименко 1872, 4). Крути'ть невесту (скрути'ть). Заготовлять невесте приданое; самое действие это называется: кру'тня, окру'тка (говорят: скрути'ть неве'сту, скрути'ть прида'ное, т.е. приготовить приданое невесте). Отсюда: крути'ться (скрути'ться) - запасать, собирать приданое (девушка безо'тная и безма'терная делает это на свои заработные деньги). Холм., Шенк. Арх. (Подвысоцкий 1885, 75-76). Завести' (заводи'ть) одежду. Готовить приданое. Молодая ещё, одежду ёй не завели ещё, без приданого она. Только начали родители одежду заводить (Галактионовская 1984) (Бунчук 2012, 69).

По севернорусской традиции, приданое перевозили в день свадьбы. Наименования чинов, перевозивших приданое, представлены в говорах следующими номинациями: Запосте'льная сватья. Женщина, обычно родственница невесты, которая отвозит в дом молодоженов постель, белье, приданое. Арх., 1849. Север. (СРНГ, X, 348). Посте'льная сватья. Родственница невесты, препровождающая ее постель и приданое в дом жениха. Онеж. Арх. (Подвысоцкий 1885, 52). Посте'льница. В свадебном обряде - женщина, которая сопровождает приданое при перевозе его в дом жениха, а также готовит постель для новобрачных. Арх., Беломор. (СРНГ, ХХХ, 223). Посте'льная проводница. Олон., Бурнашев. (СРНГ, $\mathrm{XXX}, 224)$. Пери'нщица. Родственница невесты, перевозящая ее приданое и постель в дом жениха. Арх., 1885 (СРНГ, XXVI, 282). Данные лексемы и устойчивые сочетания мотивированы постелью, которая являлась частью приданого.

Большая группа наименований чинов связана с названием ящика (короба), в котором хранили и перевозили приданое: Коробе́йник. Участник свадебного поезда, перевозящего приданое невесты в дом жениха. Влг: Хар. Коробейники 
приданое везут. Хар, Дитинская. Кто коробья вёз, тех коробейниками звали. Хар, Федоровская. Перевозчиков приданого коробейниками звали. Хар, Палковская (СГРС, 6, 45). Коробе'йники (Вол. Кадн.) Родственники невесты, привезшіе коробья съ приданымъ невесты въ домъ жениха накануне или въ день свадьбы. Ихъ (коробейниковъ) всегда у жениха стараются угостить на славу (Дилакторский, 2006, 208). Коробе́йный. Участник свадебного поезда, перевозящего приданое невесты в дом жениха. Влг: Хар. (СГРС, VI, 45). Коробе'йные. В свадебном обряде - гости, сваты или девушки-подружки, везущие приданое невесты в дом жениха. Коробейные к невесте поехали. Хар. Никул. Коробейные одёжу невестину и везли на лошади к жениху. У-К. Задн. (СВГ, ІІІ, 106). Коробе'йник. В свадебном обряде - дружка или родственник невесты, который везет приданое. Волог., 1902 (СРНГ, XIV, 345). Коробе'йница. В свадебном обряде - женщина, которая передает «приносы» от невесты родным жениха. Кольск. Арх., 1885. Слобод. Вят. (СРНГ, XIV, 345). Коробе'йные гости. В свадебном обряде - родственники невесты, которые везут приданое. Волог., 1927. Коробе’йные сваты (свахи). То же, что коробейные гости. Кадн. Волог., 1861. Волог. (СРНГ, XIV, 345).

В Архангельской и Вологодской губерниях для обозначения лиц, перевозящих приданое, функционировали наименования: Рогову'ша. Женщина, посылаемая с приданым невесты (со скрутой) в дом жениха и служащая при подклети, спальне новобрачных. Волог, 1852 (СРНГ, XXXV, 125). Рогоу'ша. Гряз. Волог., 1842 (СРНГ, XXXV, 127). Рожники'. «У поморов в г. Кеми рожники - родственники молодой - привозят постель и приданое». Арх., Богословский (СРНГ, XXXV, 154). Подку'нный (Кадн.) «Кто-либо изъ родственниковъ невесты, который съ ея постелью и имуществомъ отправляется въ домъ жениха въ то время, когда женихъ и невеста едутъ къ венцу». (Дилакторский 2006, 374). Женихо'вы золо'вки. В свадебных обрядах - молодые девушки из родственниц или знакомых жениха, которых приглашает жених в качестве подруг невесты перед свадьбой. «Так называются у Зырян молодые девицы из родственниц или знакомых жениха, который приглашает их, непременно в нечетном числе, для товарищества своей невесте вместе с ее подругами в предсвадебное время; когда жених и невеста отъезжают к венцу, жениховы золовки отвозят постель из дома невесты в дом жениха». Мезен. Арх. (Подвысоцкий, 1885; СРНГ, IX, 126).

Традиционная культура - важнейшая составляющая духовного и культурного пространства любого народа, основа формирования национального самосознания. Это широкое понятие включает народные традиции, национальные особенности духовного уклада того или иного этноса, обряды, ритуалы, праздники, ремесла. Значение и роль традиционной культуры в жизни народа неоценимы.

Народная свадьба - один из наиболее ярких образцов синкретизма слова и действий, реалий и символов. Лексика свадебного цикла является ярким подтверждением тезиса Т.И. Вендиной о том, что «в семантической структуре слова содержится богатейшая информация о системе ценностей того или иного народа, начиная с витальных и заканчивая общественно-социальными и культурными» (Вендина 1998, 6). Такое большое разнообразие названий, которые используются для выражения понятия о приданом и всего, что с ним связано, говорит о том, что приданое в крестьянском быту всегда занимало видное место. 


\section{Литература}

АОС, Архангельский областной словарь [Arhangel'skij oblastnoj slovar'], ред. О.Г. Гецова, Е.А. Нефедова [O.G. Getsova, Е.A. Nefedova], вып. 1-19, Москва 1980-2018.

Балашов Д.М., Марченко Ю.И., Калмыкова Н.И. [Balashov D.M., Marchenko Yu.I., Kalmykova N.I.] (1985), Русская свадьба: Свадебный обряд на Верхней и Средней Кокшеньге и на Уфтюге (Тарногский район Вологодской области) [Russkaya svad'ba: Svadebny'j obryad na Verhnej i Srednej Kokshen'ge i na Uftyuge (Tarnogskij rajon Vologodskoj oblasti)], Москва.

Бунчук Т.Н. [Bunchuk T.N.] (2012), Словарь русского говора села Лойма как источник этнокультурных сведений [Slovar' russkogo govora sela Lojma kak istochnik e'tnokul'turny'h svedenij], «Научный диалог», № 3, с. 64-90.

Бунчук T.Н., Пантелеева Е.В. [Bunchuk T.N., Panteleyeva E.V.] (2018), Обрядовая терминология свадьбы в говоре села Лойма Прилузского района Республики Коми [Obryadovaya terminologiya svad'by'v govore sela Lojma Priluzskogo rajona Respubliki Komi], [в:] Говоры Республики Коми и сопредельных областей: сборник материалов и исследований [Govory' Respubliki Komi i sopredel'ny'h oblastej: sbornik materialov i issledovanij], Сыктывкар, с. 6-36.

Вендина Т.И. [Vendina T.I.] (1998), Русская языковая картина мира сквозь призму словообразования (макрокосм) [Russkaya yazy'kovaya kartina mira skvoz' prizmu slovoobrazovaniya (makrokosm)], Москва.

Гура A.B. [Gura A.V.] (2011), Брак и свадьба в славянской народной культуре: Семантика и символика [Brak i svad'ba v slavyanskoj narodnoj kul'ture: Semantika i simvolika], Москва.

Дилакторский П.А. [Dilaktorskiy P.A.] (2006), Словарь областного вологодского наречия в его бытовом и этнографическом применении [Slovar' oblastnogo vologodskogo narechiya $v$ ego by'tovom i e'tnograficheskom primenenii], по рукописи П.А. Дилакторского 1902 г., изд. подгот. А.Н. Левичкин [A.N. Levichkin] и C.A. Мызников [S.A. Myznikov], С.-Петербург.

Дранникова Н.В. [Drannikova N.V.] (2001), Фольклор Архангельского края (из материалов лаборатории фольклора) [Fol'klor Arhangel'skogo kraya (iz materialov laboratorii fol'klora)], Архангельск.

Ефименко П. [Yefimenko Р.] (1872), Приданое по обычному праву крестьян Архангельской губернии [Pridanoe po oby'chnoти pravu krest'yan Arhangel'skoj gubernii]. С.-Петербург.

Журавлев А.Ф. [Zhuravlev A.F.] (1992), Лексикостатистическое моделирование системы славянского языкового родства [Leksikostatisticheskoe modelirovanie sistemy' slavyanskogo yazy'kovogo rodstva], автореф. дисс. ... докт. филол. наук, Москва.

Крестьянское искусство СССР. Искусство Севера [Krest'yanskoe iskusstvo SSSR. Iskusstvo Severa], Ленинград 1928.

Круглова Ю.Г. [Kruglova Yu.G.] (2001), Жизнь человека в русском фольклоре. Свадьба [Zhizn' cheloveka v russkom fol'klore. Svad'ba], Москва.

Куликовский Г.И. [Kulikovskiy G.I.] (1989), Словарь областного олонеикого наречия в его бытовом и этнографическом применении [Slovar' oblastnogo olonechkogo narechiya $v$ ego by'tovom i e'tnograficheskom primenenii], С.-Петербург.

Подвысоцкий А. [Podvysotskiy А.] (1885), Словарь областного арһангельского наречия в его бытовом и этнографическом применении [Slovar' oblastnogo arhangel'skogo narechiya $v$ ego by'tovom i e'tnograficheskom primenenii], Санкт-Петербург. 
Русский народ. Его обычаи, обряды, предания, суеверия и поэзия [Russkij narod. Ego oby'chai, obryady', predaniya, sueveriya i poe'ziya], собр. М. Забылиным [M. Zabylin], Москва 1996.

СВГ, Словарь вологодских говоров [Slovar' vologodskih govorov], вып. 1-7, ред. Т.Г. Паникаровская [T.G. Panikarovskaya], вып. 8-12, Т.Г. Паникаровская [T.G. Panikarovskaya], Л.Ю. Зорина [L.Yu. Zorina], Вологда 1983-2007.

СГРС, Словарь говоров Русского Севера [Slovar' govorov Russkogo Severa], т. 1-5, ред. А.К. Матвеев [А.К. Matveyev], т. 6-7, гл. ред. М.Э. Рут [M.Е. Rut], Екатеринбург 20012018.

Словарь диалектных слов Усть-Кубинского района Вологодской области [Slovar' dialektny'h slov Ust'-Kubinskogo rajona Vologodskoj oblasti], сост. Морозкова 3.A. [Morozkova Z.A.], Устье 2017.

СРГК, Словарь русских говоров Карелии и сопредельных областей [Slovar' russkih govorov Karelii i sopredel'ny'h oblastej]: в 6-ти т., гл. ред. А.С. Герд [A.S. Gerd], С.-Петербург 1994-2004.

СРНГ, Словарь русских народных говоров [Slovar' russkih narodny'h govorov], гл. ред. Ф.П. Филин, Ф.П. Сороколетов, С.А. Мызников [F.P. Filin, F.P. Sorokoletov, S.A. Myznikov], т. I-LI, Москва - Ленинград - С.-Петербург 1965-2019.

Толстой Н.И. [Tolstoy N.I.] (1982), Диалектология в этнолингвистической перспективе [Dialektologiya v e'tnolingvisticheskoj perspektive], [в:] Системные отношения в лексике севернорусских говоров [Sistemny'e otnosheniya v leksike severnorusskih govorov], Вологда, с. $3-7$.

Шаповалова Г.Г., Лаврентьева Л.С. [Shapovalova G.G., Lavrent'yeva L.S.] (1998), Жили-бьли... Русская обрядовая поэзия [Zhili-by'li... Russkaya obryadovaya poe'ziya], С.-Петербург.

Шевченко E.A. [Shevchenko E.A.] (2010), Свадебный обряд Лузского района Кировской области (функииональные аспекты поэтических жанров) [Svadebny'j obryad Luzskogo rajona Kirovskoj oblasti (funkcional'ny'e aspekty' poe'ticheskih zhanrov], Сыктывкар.

Шейн П.В. [Sheyn P.V.] (1898), Великорус в своих песнях, обрядах, обычаях, верованиях, сказках, легендах [Velikorus $v$ svoih pesnyah, obryadah, oby'chayah, verovaniyah, skazkah, legendah], С.-Петербург. 